\title{
BASE-COMBINING CAPACITY OF WOOL
}

\author{
By Milton Harris and Henry A. Rutherford ${ }^{1}$
}

\begin{abstract}
It is shown that the failure of wool to reach equilibrium with alkaline solutions under the conditions of titration experiments is due to the reaction of base with the disulfide groups of the cystine. The results indicate that the extent of this reaction can be determined. The data also afford confirmation of the earlier observation that the alkali degradation of the cystine in wool involves the loss of only one sulfur atom from each cystine residue.

The apparent base-combining capacity increases with increasing duration of contact of wool with alkali and with increasing temperature, but the intrinsic base-combining capacity, obtained by making corrections for the dissolved protein and for the base bound by the sulfhydryl groups, becomes constant after approximately 2 hours. The most consistent data are obtained at a low temperature, where, it appears, secondary reactions are greatly inhibited.

Determination of the amount of base absorbed from solutions of various concentrations indicates that a limiting amount of about 0.7 millimole per gram of wool is reached above concentrations of about $0.2 \mathrm{~N}$ sodium hydroxide. Because of discrepancies in the data obtained at concentrations greater than $0.3 \mathrm{~N}$, it is suggested that this value be considered for the present as tentative.
\end{abstract}

\section{CONTENTS}

I. Introduction _. . . .

II. Experimental procedure

1. Materials_............ 536

2. Methods_....... 537

III. Results and discussion

1. Effect of sodium hydroxide on the cystine in wool

2. Absorption of alkali as a function of time

IV. Conclusionsorption of base from solutions of various concentrations..-

\section{INTRODUCTION}

Many properties of wool are intimately related to the number of acidic and basic groups which it contains. Because of the stability of wool in acid solutions, few difficulties are encountered in determining the acid-combining capacity, which apparently reaches a maximum of about 0.80 millimole per gram of wool at about $\mathrm{pH} 1[1]{ }^{2}$ In the alkaline region, however, there has been no indication of a maximum base-combining capacity or of a stoichiometric end point, and as a result, very little knowledge concerning the number of acidic groups in wool can be deduced from published titration data.

The results of recent investigations by Crowder and Harris [2] on the nature of the degradation of wool protein in alkaline solutions

\footnotetext{
1 Research Associates at the National Bureau of Standards, representing the Textlle Foundation.

' Figures in brackets indicate the literature references at the end of this paper.
} 
suggested that the chief difficulty in determining the base-combining capacity arises from the fact that the alkali reacts not only with the free acidic groups, but also with the disulfide groups of the cystine in the protein. It appears that the primary process in the cleavage by alkali of the disulfide linkage consists in a hydrolytic rupture with the formation of a sulfhydryl compound and a sulfenic acid. The latter is unstable in alkaline solution and immediately loses hydrogen sulfide. The general scheme is given in the equations

$$
\begin{gathered}
\mathrm{RCH}_{2}-\mathrm{S}-\mathrm{S}-\mathrm{CH}_{2} \mathrm{R}+2 \mathrm{NaOH} \rightarrow \mathrm{RCH}_{2} \mathrm{SNa}+\mathrm{RCH}_{2} \mathrm{SONa}+\mathrm{H}_{2} \mathrm{O} \\
\mathrm{RCH}_{2} \mathrm{SONa} \rightarrow \mathrm{RCHO}+\mathrm{NaHS}
\end{gathered}
$$

The sulfhydryl and the sulfenic compounds, formed according to eq 1 , are both acidic, and accordingly, 2 moles of base are taken up in the cleavage of each disulfide group. However, 1 mole is liberated in the breakdown of the sulfenic acid, as shown in eq 2 . If the above mechanism is correct, the amount of inorganic sulfide sulfur (NaHS) formed during treatment of wool with a basic solution should be a measure not only of the number of disulfide groups hydrolyzed but also of the amount of base taken up by the sulfhydryl group formed in the wool.

The purpose of the present investigation was to study the absorption of base by wool from the viewpoint of the above hypothesis. It was intended that these studies form a background for the investigation of the basic portion of the complete titration curves.

\section{EXPERIMENTAL PROCEDURE}

\section{MATERIALS}

It has been demonstrated in this laboratory and elsewhere [3] that the disulfide group of the cystine in wool is readily attacked by light. Since it was necessary to know the number of disulfide groups which were split during the alkali treatment of the wool, considerable care was exercised in choosing suitable samples for these measurements. Obviously, it was particularly desirable to have the bulk of the sulfur in the form of intact disulfide groups.

Two types of materials were used in these experiments, namely, raw-wool fibers and a specially prepared wool yarn. The former were divided into three approximately equal sections, which were designated as the root, middle, and tip portions of the fiber. Each portion was purified by extraction with alcohol and ether and finally washed with distilled water. The analyses given in table 1 show that both the sulfur and cystine contents decrease from the root to the tip of the fiber, but that only in the tip portion has an appreciable amount of the cystine been destroyed.

The yarn was prepared from raw wool which had been extracted with Stoddard solvent and washed with water. It was further purified as described above. Determination of the total sulfur and cystine contents showed that 97 percent of the former could be accounted for as cystine sulfur, thus indicating that very little photochemical deterioration had occurred. The data reported in this work were obtained on root wool or yarn. 
TABLE 1.-Sulfur and cystine contents of the root, middle, and tip portions of wool fibers

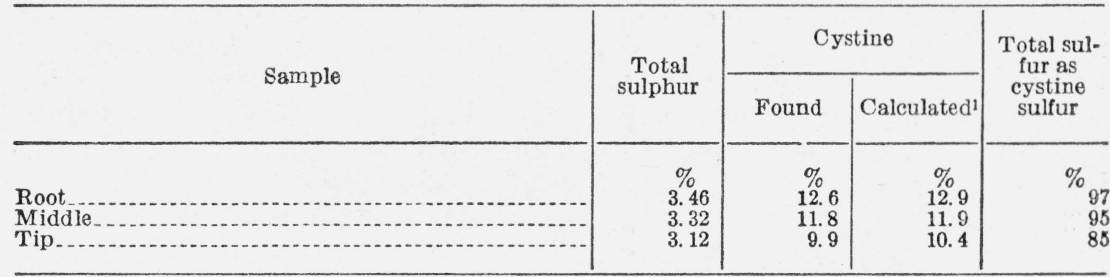

1 Calculated from total sulfur, assuming that the destruction of each molecule of cystine involves the loss of only 1 atom of sulfur.

\section{METHODS}

The complete experimental procedure was as follows. Samples of wool weighing approximately $1 \mathrm{~g}$ were dried in an oven at $105^{\circ} \mathrm{C}$. After each sample was dried and weighed it was treated with $50 \mathrm{ml}$ of a sodium-hydroxide solution at $0^{\circ}$ to $2^{\circ} \mathrm{C}$ (air bath) or $22^{\circ} \mathrm{C}$. At the end of a given time, the supernatant liquor was poured off. A 5-ml aliquot was taken for nitrogen analysis, a $20-\mathrm{ml}$ aliquot for inorganic sulfide sulfur analysis, and a $20-\mathrm{ml}$ aliquot for volumetric titration with hydrochloric acid, using methyl red as the indicator. In some of the experiments, an excess of a cold solution of $0.1 \mathrm{~N}$ hydrochloric acid was immediately added to the residual wool to prevent further degradation of the fibers. The fibers were allowed to remain in the acid for 1 day and were then washed for 4 days in running distilled water. Finally, the cystine content of each sample was determined.

Nitrogen was determined by the micro-Kjeldahl method, total sulfur by the oxygen-bomb [4], and cystine by the Sullivan method [5]. In the latter determination, the wool was hydrolyzed with a hydrochloric-formic acid mixture, as described by Miller and du Vigneaud [6], and the color measured by the method described by Harris and Smith [7].

The inorganic sulfide sulfur was determined by the following procedure. An excess of bromine was immediately added ${ }^{3}$ to the solution. The mixture was allowed to stand for several minutes, then acidified with hydrochloric acid, and finally warmed on a steam bath until free from bromine. The sulfate was precipitated as the barium salt and determined in the usual manner.

The apparent base-combining capacity is the value obtained directly from the measurement of the total amount of sodium hydroxide removed from the solution by the wool. The intrinsic base-combining capacity is the amount of base bound by the free acidic groups of the nondegraded wool. To obtain this, two corrections must be introduced. One of these is small, but the other will be shown to be very important.

The first correction, which is the less important, results from the conversion of a portion of the original wool into a soluble form during the treatment with alkali. Since methyl red was used as the indicator, the base bound by the dissolved material is neutralized during the titration. In order to correct for this effect and to obtain only the absorption by the insoluble portion of wool, it is necessary to sub-

\footnotetext{
Sulfur in wool or in cystine is not oxidized to sulfate under these conditions.
} 
tract the weight of the soluble fraction from the original weight of untreated material. The former is readily calculated from the nitrogen in the solution, since it has previously been shown [8] that the loss of nitrogen from wool during alkaline treatment is proportional to the loss in weight of the wool.

The second correction is for the base bound by sulfhydryl groups formed in the degradation of the disulfide groups of the cystine according to eq 1 and 2 . The amount of base taken up as a result of these reactions is calculated from the inorganic sulfide sulfur which has gone into solution.

\section{RESULTS AND DISCUSSION}

\section{EFFECT OF SODIUM HYDROXIDE ON THE CYSTINE IN WOOL}

The mechanism suggested [2] for the alkali degradation of the cystine in wool involves the loss of only one sulfur atom for each disulfide group. In order to further test this hypothesis, a series of wool samples was treated with a $0.1 \mathrm{~N}$ solution of sodium hydroxide for different lengths of time at $0^{\circ}$ to $2^{\circ} \mathrm{C}$ and at $22^{\circ} \mathrm{C}$, the solutions and wool being handled as previously described. The effect of the treatment on the cystine is shown in table 2. Good agreement was obtained between the experimentally determined cystine values and those calculated from the loss in sulfur. Appreciable discrepancies occurred only in the experiments in which the wool was severely degraded by prolonged contact with the alkali.

\section{ABSORPTION OF ALKALI AS A FUNCTION OF TIME}

The time necessary to attain equilibrium was determined by measuring the absorption of base from $0.1 \mathrm{~N}$ solutions of sodium hydroxide. The data given in tables 3 and 4 were obtained at $0^{\circ}$ to $2^{\circ} \mathrm{C}$ and at $22^{\circ} \mathrm{C}$, respectively.

TABLE 2.-Degradation of cysine in wool by $0.1 \mathrm{~N}$ solutions of sodium hydroxide at $0^{\circ}$ to $\mathscr{Z}^{\circ} \mathrm{C}$ and at $22^{\circ} \mathrm{C}$ as a function of time

\begin{tabular}{|c|c|c|c|c|c|c|}
\hline \multirow{3}{*}{ Time } & \multicolumn{3}{|c|}{$0^{\circ}$ to $2^{\circ} \mathrm{C}$} & \multicolumn{3}{|c|}{$22^{\circ} \mathrm{C}$} \\
\hline & \multirow{2}{*}{$\begin{array}{l}\text { Inorganic } \\
\text { sulfide } \\
\text { sulfur in } \\
\text { solution }\end{array}$} & \multicolumn{2}{|c|}{ Cystine } & \multirow{2}{*}{$\begin{array}{l}\text { Inorganic } \\
\text { sulfide } \\
\text { sulfur in } \\
\text { solution }\end{array}$} & \multicolumn{2}{|c|}{ Cystine } \\
\hline & & Calc.1 & Expt. & & Calc. ${ }^{1}$ & Expt. \\
\hline$h r$. & $\underset{\text { wool }}{m g / g m}$ of & $\%$ & $\%$ & $\underset{\text { wool }}{m g / g m}$ of & $\%$ & $\%$ \\
\hline $\begin{array}{l}0.5 \\
1.0 \\
1.5 \\
2\end{array}$ & $\begin{array}{r}0.44 \\
.46 \\
.50 \\
.62\end{array}$ & $\begin{array}{l}11.8 \\
11.8 \\
11.7 \\
11.6\end{array}$ & $\begin{array}{l}11.8 \\
11.9 \\
11.5 \\
11.6\end{array}$ & $\begin{array}{l}1.10 \\
1.49 \\
2.21 \\
2.70\end{array}$ & $\begin{array}{l}11.5 \\
11.2 \\
10.6 \\
10.2\end{array}$ & $\begin{array}{r}12.9 \\
11.9 \\
10.9 \\
9.9\end{array}$ \\
\hline $\begin{array}{l}3.25 \\
5 \\
6.5\end{array}$ & $\begin{array}{l}.71 \\
.82 \\
.98\end{array}$ & $\begin{array}{l}11.6 \\
11.5 \\
11.4\end{array}$ & $\begin{array}{l}11.5 \\
11.4 \\
11.2\end{array}$ & $\begin{array}{l}3.80 \\
5.02\end{array}$ & $\begin{array}{l}9.4 \\
8.5\end{array}$ & $\begin{array}{l}9.1 \\
8.9\end{array}$ \\
\hline & $\begin{array}{l}\text { 1. } 14 \\
\text { 2. } 27\end{array}$ & $\begin{array}{l}11.2 \\
10.4\end{array}$ & $\begin{array}{l}11.3 \\
10.2\end{array}$ & $\begin{array}{l}6.18 \\
9.34\end{array}$ & $\begin{array}{l}7.7 \\
5.3\end{array}$ & $\begin{array}{l}7.7 \\
6.1\end{array}$ \\
\hline $\begin{array}{r}48 \\
90 \\
240\end{array}$ & $\begin{array}{l}3.85 \\
6.02 \\
9.36\end{array}$ & $\begin{array}{l}9.2 \\
7.6 \\
5.1\end{array}$ & $\begin{array}{l}9.0 \\
8.1 \\
6.3\end{array}$ & $\begin{array}{l}12.12 \\
14.00\end{array}$ & $\begin{array}{l}3.2 \\
1.8\end{array}$ & $\begin{array}{l}5.0 \\
4.2\end{array}$ \\
\hline
\end{tabular}

1 These values were calculated on the basis that each atom of inorganic sulfide sulfur found in solution represented the destruction of a molecule of cystine. 
TABLE 3.-Absorption of base from $0.1 \mathrm{~N}$ solutions of sodium hydroxide at $0^{\circ}$ to $\mathscr{2}^{\circ} \mathrm{C}$ as a function of time

\begin{tabular}{|c|c|c|c|c|c|c|}
\hline & 1 & 2 & 3 & 4 & 5 & 6 \\
\hline Time & $\begin{array}{l}\text { Nitrogen } \\
\text { in solu- } \\
\text { tion }\end{array}$ & $\begin{array}{l}\text { Inorganic } \\
\text { sulfide } \\
\text { sulfur in } \\
\text { solution }\end{array}$ & $\begin{array}{l}\text { Apparent } \\
\text { base-combin- } \\
\text { ing capacity }\end{array}$ & $\begin{array}{l}\text { Base-combin- } \\
\text { ing capacity } \\
\text { corrected for } \\
\text { dissolved } \\
\text { protein }\end{array}$ & $\begin{array}{c}\text { Base bound } \\
\text { by suifhydryl } \\
\text { groups formed } \\
\text { according to } \\
\text { eq } 1 \text { and } 2\end{array}$ & $\begin{array}{c}\text { Intrinsic } \\
\text { base-combin- } \\
\text { ing capacity } \\
(4-5)\end{array}$ \\
\hline $\begin{array}{l}h r . \\
0.50 \\
.75 \\
1.00 \\
1.5 \\
2\end{array}$ & $\begin{array}{c}m g / g m 1 \\
0.52 \\
.54 \\
.71 \\
.93 \\
.92\end{array}$ & $\begin{array}{c}m g / g m \\
0.44 \\
.40 \\
.46 \\
.50 \\
.62\end{array}$ & $\begin{array}{c}\text { Millimoles' } \\
\text { gm } \\
0.50 \\
.56 \\
.57 \\
.58 \\
.58\end{array}$ & $\begin{array}{c}\text { Millimoles/ } \\
\text { gm } \\
0.50 \\
.56 \\
.57 \\
.58 \\
.58\end{array}$ & $\begin{array}{c}\text { Millimoles/ } \\
\text { gm } \\
0.014 \\
.013 \\
.014 \\
.016 \\
.019\end{array}$ & $\begin{array}{c}\text { Millimoles/ } \\
\text { gm } \\
0.49 \\
.55 \\
.56 \\
.56 \\
.56\end{array}$ \\
\hline $\begin{array}{l}3.25 \\
5 \\
6.5 \\
8 \\
20\end{array}$ & $\begin{array}{l}1.20 \\
1.42 \\
1.56 \\
1.94 \\
2.61\end{array}$ & $\begin{array}{r}.71 \\
.82 \\
.98 \\
\text { 1. } 14 \\
2.27\end{array}$ & $\begin{array}{l}.59 \\
.60 \\
.60 \\
.61 \\
.63\end{array}$ & $\begin{array}{l}.59 \\
.61 \\
.61 \\
.62 \\
.64\end{array}$ & $\begin{array}{l}.022 \\
.026 \\
.031 \\
.036 \\
.071\end{array}$ & $\begin{array}{l}.57 \\
.58 \\
.58 \\
.58 \\
.57\end{array}$ \\
\hline $\begin{array}{r}48 \\
90 \\
240\end{array}$ & $\begin{array}{l}\text { 3. } 70 \\
4.57 \\
5.47\end{array}$ & $\begin{array}{l}3.85 \\
6.02 \\
9.36\end{array}$ & $\begin{array}{l}.68 \\
.72 \\
.85\end{array}$ & $\begin{array}{l}.70 \\
.74 \\
.88\end{array}$ & $\begin{array}{l}120 \\
.188 \\
.293\end{array}$ & $\begin{array}{l}.58 \\
.55 \\
.59\end{array}$ \\
\hline
\end{tabular}

1 All values in this trble are in terms of grams of dry wool.

TABLE 4.-Absorption of base by wool from $0.1 \mathrm{~N}$ solutions of sodium hydroxide at $22^{\circ} \mathrm{C}$ as a function of time

\begin{tabular}{|c|c|c|c|c|c|c|}
\hline & 1 & 2 & 3 & 4 & 5 & 6 \\
\hline Time & $\begin{array}{l}\text { Nitrogen } \\
\text { in solu. } \\
\text { tion }\end{array}$ & $\begin{array}{l}\text { Inorganic } \\
\text { sulfide } \\
\text { sulfur in } \\
\text { solution }\end{array}$ & $\begin{array}{c}\text { Apparent } \\
\text { hase-combin- } \\
\text { ing capacity }\end{array}$ & $\begin{array}{l}\text { Base-combin- } \\
\text { ing capacity } \\
\text { corrected for } \\
\text { dissolved } \\
\text { protein }\end{array}$ & $\begin{array}{c}\text { Base bound } \\
\text { hy sulfhydryl } \\
\text { groups formed } \\
\text { according to } \\
\text { eq } 1 \text { and } 2\end{array}$ & $\begin{array}{c}\text { Intrinsic } \\
\text { base-combin- } \\
\text { ing capacity } \\
(4-5)\end{array}$ \\
\hline $\begin{array}{l}\text { hr. } \\
0.5 \\
1.0 \\
1.5 \\
2.0 \\
3.25\end{array}$ & $\begin{array}{c}m g / g m^{1} \\
1.05 \\
1.86 \\
2.31 \\
2.91 \\
3.66\end{array}$ & $\begin{array}{c}m g / g m \\
1.10 \\
1.49 \\
2.21 \\
2.70 \\
3.80\end{array}$ & $\begin{array}{c}\text { Millimoles/ } \\
\text { gm } \\
0.54 \\
.61 \\
.59 \\
.61 \\
.63\end{array}$ & $\begin{array}{c}\text { Millimoles/ } \\
\text { gm } \\
0.54 \\
.62 \\
.60 \\
.62 \\
.65\end{array}$ & $\begin{array}{c}\text { Millimoles/ } \\
\text { gm } \\
0.034 \\
.047 \\
.069 \\
.084 \\
.119\end{array}$ & $\begin{array}{c}\text { Millimoles' } \\
0 m \\
0.51 \\
.57 \\
.53 \\
.54 \\
.53\end{array}$ \\
\hline $\begin{array}{r}5 \\
8 \\
20 \\
48 \\
90\end{array}$ & $\begin{array}{c}4.18 \\
4.73 \\
6.43 \\
7.00 \\
10.5\end{array}$ & $\begin{array}{r}5.02 \\
6.18 \\
9.34 \\
12.12 \\
14.00\end{array}$ & $\begin{array}{l}.64 \\
.70 \\
.74 \\
.80 \\
.94\end{array}$ & $\begin{array}{r}.66 \\
.72 \\
.77 \\
.84 \\
1.00\end{array}$ & $\begin{array}{l}.157 \\
.193 \\
.293 \\
.378 \\
.438\end{array}$ & $\begin{array}{l}.50 \\
.53 \\
.48 \\
.46 \\
.56\end{array}$ \\
\hline
\end{tabular}

All values in this table are in terms of grams of dry wool.

Figure 1 shows that at $0^{\circ}$ to $2^{\circ} \mathrm{C}$ the apparent base-combining capacity increased with increasing time of treatment, whereas the intrinsic base-combining capacity became constant after about 2 hours. The former arose, as shown in column 5 of table 3 , from the combination of the base with sulfhydryl groups which were continuously formed in the degradation of the cystine. The amount of base which reacted in this manner increased with increasing time of treatment. After 240 hours, the correction amounted to 35 percent of the apparent value. On the other hand, the correction for the dissolved protein was negligible up to 5 hours and amounted to only 0.03 millimole per gram of wool after 240 hours. The constancy of the corrected values is shown in column 6 and indicates the absence of appreciable secondary reactions. 
The intrinsic base-combining capacities obtained at $22^{\circ} \mathrm{C}$, as shown in table 4, appear to be somewhat lower and considerably more erratic than those obtained at $0^{\circ}$ to $2^{\circ} \mathrm{C}$. This may be attributed to several factors. The rate of degradation as indicated by the amount of dissolved nitrogen (column 1, tables 3 and 4) was much greater at the higher temperature; for example, approximately the same amount of degradation occurred in $3 \frac{1}{4}$ hours at $22^{\circ} \mathrm{C}$ as occurred in 48 hours at $0^{\circ}$ to $2^{\circ} \mathrm{C}$. It was also noticed that the reproducibility of the titrations decreased as the amount of degradation increased. The chief difficulty appeared to result from the effect of the dissolved protein on the sharpness of the end point. Finally, an error was intro-

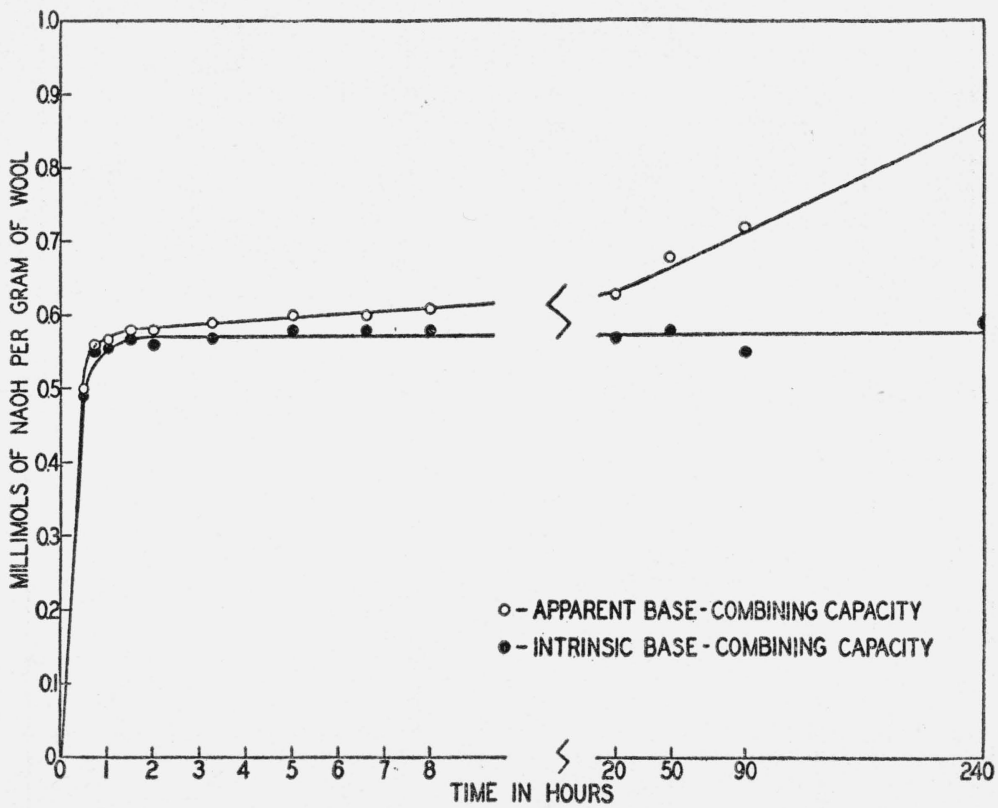

FIGURe 1.-Rate of absorption of base from $0.1 \mathrm{~N}$ solutions of sodium hydroxide at $0^{\circ}$ to $2^{\circ} \mathrm{C}$.

duced, since some sulfhydryl groups were probably present in the dissolved protein. The base bound by these groups was neutralized on addition of acid, and since the data in column 5 were calculated on the assumption that all of the sulfhydryl groups formed according to eq 1 and 2 bind base, these values may be too large. In the case of the low-temperature experiments, and especially for the shorter periods of time, this error is shown to be negligible (table 3 ). However, at $22^{\circ} \mathrm{C}$ the amount of protein which goes into solution may contain a sufficient number of sulfhydryl groups to account for a large portion of the discrepancy between the values obtained at this temperature and those obtained at $0^{\circ}$ to $2^{\circ} \mathrm{C}$.

\section{ABSORPTION OF BASE FROM SOLUTIONS OF VARIOUS CONCENTRATIONS}

The effect of varying the concentration of base is shown in figure 2 . The absorptions were measured at $0^{\circ}$ to $2^{\circ} \mathrm{C}, 2$ hours being allowed to attain equilibrium. That equilibrium was reached under these 
conditions in the most dilute and most concentrated solutions used was indicated by measurements made after 2 and 20 hours.

Each point represents the average of four determinations. Good agreement between the individual determinations for each concentration of alkali up to about $0.3 \mathrm{~N}$ was obtained. Above that concentration, there was considerable variation, as indicated by the dotted lines perpendicular to the lower curve, which show the spread of the values obtained. The discrepancies may have resulted from secondary reactions which occurred in the strongly alkaline solutions, or from the small temperature variations in the air bath used in this work.

The amount of base combined changes very little when the concen-

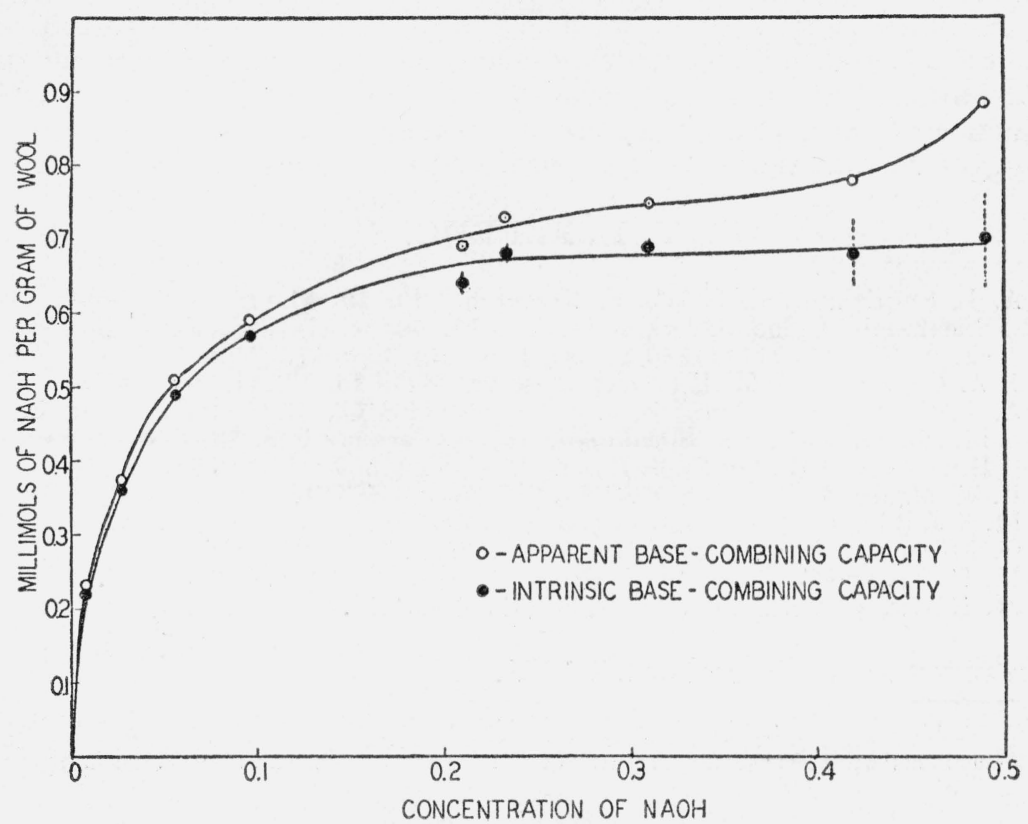

FIGURE 2.-Absorption of base from solutions of various concentrations.

The broken vertical lines indicate the maximum variations in the values obtained.

tration of base exceeds $0.2 \mathrm{~N}$ and appears to approach a limiting value of about 0.70 millimole of base per gram of wool.

\section{CONCLUSIONS}

The results of the present study show that the failure of wool ${ }^{4}$ to reach equilibrium with alkaline solutions under the conditions of titration experiments is due to the reaction of base with disulfide groups of the cystine. It is demonstrated that the extent of this reaction can be determined.

The data afford confirmation of the earlier observation [2] that the alkali degradation of the cystine in wool involves the loss of only one sulfur atom from each cystine molecule. The remaining sulfur is apparently present in the form of sulfhydryl groups. On the basis

4 This demonstrably applies to other cystine-containing proteins. 
of this mechanism, it is possible to calculate the amount of base taken up in the degradation of the disulfide groups.

The apparent base-combining capacity increases with increasing duration of the contact of wool with alkali and with increasing temperature of the alkaline solutions, but the intrinsic base-combining capacity, obtained by making corrections for the dissolved protein and for the base bound by the sulfhydryl groups, becomes constant after approximately 2 hours. The results show that the more consistent data are obtained at the lower temperature where, it appears, secondary reactions are greatly inhibited.

Determination of the amount of base absorbed from solutions of various concentrations indicates that a limiting amount of about 0.7 millimole per gram of wool is reached above concentrations of about $0.2 N$ sodium hydroxide. Since some discrepancies occur in the data obtained at high concentrations of alkali, and since the possible influence of the naturally occurring ash has not been considered, it is suggested that this value be considered for the present as tentative. ${ }^{s}$

\section{REFERENCES}

[1] A. L. Smith and M. Harris, J. Research NBS 19, 81 (1937) RP1012; J. B. Speakman, J. Soc. Dyers Colourists 40, 408 (1924); E. Elod, Ber. deut. chem. Ges. 53, 2164 (1920); Porai-Koschitz, J.prakt. Chem. 13\%, 179 (1933).

[2] J. A. Crowder and M. Harris, J. Research NBS 16, 479 (1936) RP885.

[3] A. L. Smith and M. Harris, J. Research NBS 1\%, 97 (1936) RP904; P. R. McMahon and J. B. Speakman, Trans. Faraday Soc. 33, 844 (1937); M. Harris and A. L. Smith, J. Research NBS 20, 563 (1938) RP1091.

[4] R. T. Mease, J. Research NBS 13, 617 (1934) RP721.

[5] M. X. Sullivan, Public Health Reports 86, (1930).

[6] G. Miller and V. du Vigneaud, J. Biol. Chem. 118, 101 (1937).

[7] M. Harris and A. L. Smith, J. Research NBS 18, 623 (1937) RP998.

[8] M. Harris, J. Research NBS 15, 63 (1935) RP810.

Washington. December 27, 1938.

- Further work, in which experiments are being made in a water thermostat which can he regulated to $0.02^{\circ} \mathrm{C}$, is now in progress. The effect of the ash is also being studied. For these reasons, a discussion of the stoichiometry of the reaction of base with the free acidic groups in wool is not presented at this time. 